\title{
COMPARISON OF BASIC LIMNOLOGICAL ASPECTS OF SOME CRATER LAKES IN THE CORDILLERA VOLCÁNICA CENTRAL, COSTA RICA
}

\author{
COMPARACIÓN DE ASPECTOS LIMNOLÓGICOS BÁSICOS DE ALGUNOS LAGOS \\ CRATÉRICOS EN LA CORDILLERA VOLCÁNICA CENTRAL, COSTA RICA
}

\author{
Gerardo Umaña
}

\author{
CIMAR \\ Escuela de Biología, Universidad de Costa Rica \\ gerardo.umana@ucr.ac.cr
}

(Recibido: 20/08/2009; aceptado: 08/11/2010)

\begin{abstract}
Crater lakes share some morphological characteristics such as size, shape, situation inside a crater, usually high elevation, which have a definite impact on their limnology. In Costa Rica there are several crater lakes that may serve as an example of small tropical lakes to examine some relationships between morphometry and stratification. The results of different limnological expeditions to four such lakes are presented. The lakes are Barva, Botos, Cerro Chato and Hule. These lakes differ in their size and altitude. During each expedition the water transparency, the vertical profiles of oxygen and temperature were measured in a station at the middle of each lake as part of a more compressive study. The lakes were visited on several occasions for at least one year or more. The lakes which were relatively deep for their size, as judged from their relative depth such as Barva ( $\mathrm{Zmax}=7 \mathrm{~m}, \mathrm{Zr}=6.2,2840$ masl) and Cerro Chato $(\mathrm{Zmax}=18 \mathrm{~m}, \mathrm{Zr}=9.6,1020 \mathrm{mas})$, showed signs of frequent stratification, although at higher elevations and in the shallow Barva Lake this stratification may lasts only for short periods, whereas in deeper Cerro Chato Lake the mixing is mainly seasonal. On the other hand, Botos Lake $(\mathrm{Zmax}=9 \mathrm{~m}, \mathrm{Zr}=2.5,2600$ masl) that is relatively shallow for their size and widely exposed to the wind action, is clearly continuous polymictic, notwithstanding that its absolute depth is similar to smaller Barva, and finally Hule, a deep, exposed lake, but at low elevation is clearly oligomictic.
\end{abstract}

Keywords: limnology, crater lakes, water column, morphometry, Costa Rica.

RESUMEN: Los lagos cratéricos comparten algunas características morfológicas como tamaño, forma, situación dentro de un cráter, usualmente de alta elevación, los cuales tienen un impacto definitivo en su limnología. En Costa Rica existen varios lagos cratéricos que pueden servir como ejemplos de lagos tropicales pequeños para examinar algunas relaciones entre la morfología y la estratificación. Se presentan los resultados de diferentes expediciones limnológicas 
a cuatro de estos lagos. Los lagos son Barva, Botos, Cerro Chato y Hule. Estos lagos difieren en su tamaño y altitud. Durante cada expedición se hicieron mediciones de la trasparencia del agua, los perfiles verticales de oxígeno disuelto y temperatura, en una estación en el centro de cada lago, como parte de un estudio más comprensivo de los lagos de Costa Rica. Los lagos se visitaron en varias ocasiones al menos por un año o más. Los lagos que fueron relativamente profundos para su tamaño, a juzgar por su profundidad relativa como Barva ( $\mathrm{Zmax}=7 \mathrm{~m}, \mathrm{Zr}=6,2 ; 2840 \mathrm{msnm})$ and Cerro Chato $(\mathrm{Zmax}=18 \mathrm{~m}, \mathrm{Zr}=9.6,1020 \mathrm{msnm})$, mostraron signos de frecuente estratificación, aunque en el lago Barva, a mayor altitud pero de menor profundidad, la estratificación puede durar solamente por periodos breves, mientras que en el lago del Cerro Chato, de mayor profundidad, la mezcla es principalmente estacional. Por otro lado, el lago Botos $(Z \max =9 \mathrm{~m}, \mathrm{Zr}=2.5,2600 \mathrm{msnm})$ que es relativamente somero para su tamaño y está muy expuesto a la acción del viento, es claramente polimíctico, a pesar de que su profundidad es similar a la del lago Barva. Finalmente, el lago Hule, un lago profundo, expuesto al viento, pero a una menor elevación, es claramente oligomíctico.

Palabras clave: limnología, lagos cratéricos, columna de agua, morfometría, Costa Rica.

\section{INTRODUCTION}

In the recent past there has been a development on limnological research of small tropical lakes in Costa Rica (Haberyan \& Horn, 1999; Haberyan et al., 1995, 2003; Horn \& Haberyan, 1993; Umaña, 1990, 1993, 1997, 2001; Umaña \& Jiménez, 1995). Among many different types of lakes in this small, but topographically varied country, the crater lakes are important representatives.

Crater lakes are common in volcanic regions, and have been studied for example in Africa (Baxter et al., 1965; Melack, 1978; Kling, 1988; Chapman et al., 1998), New Zealand (Chapman et al., 1981), Costa Rica (Umaña, 1990; Umaña \& Jiménez, 1995; Umaña, 2001), Ecuador (Gunkel \& Casallas, 2002) and Mexico (Vásquez, et al. 2004). Several generalizations can be withdrawn from all such studies. Crater lakes tend to be small, with regular, circular shapes; they can be of considerable depth for their size, with steep slopes from their shore. They are usually within the rim of the crater that rises right from the lake shore and protect them from wind exposure. Their drainage basin is usually quite small, restricted to the crater rim at the summit of the volcano. As a result, crater lakes fill with rain water and are usually very dilute, with low buffer capacity and low productivity. Their dynamics and seasonal variation is partially affected by these facts and comparative studies have tried to elucidate the relative effect of each factor.
In Costa Rica there are crater lakes in Poás volcano, Barva, Cerro Chato, Hule and Congo lakes in the craters of Bosque Alegre, Río Cuarto, Rincón de la Vieja. There are other lakes associated with volcanic activities like lava flows which block small drainages. Most volcanic buildings in Costa Rica are complexes that resulted from the accumulation of past eruptions and the eruptive activity along a cortical fracture at the base of the complex. At the same time, the formation of volcano-tectonic depressions (i.e. grabens) has created some of the current crater lakes (Alvarado et al., 2000). All this activity has resulted in lakes of varied morphology and size, as well as variation in the topography of the drainage basin of the crater it self. Some are wider or deeper than the other. This varied setting may have a significant effect on the limnological characteristics of the lakes contained within the crater such as surface area, depth, exposure to the wind. Consequently, the behavior of the water column stratification, with its consequences on water chemistry, may be affected as well.

In this brief paper the information on the variation of the water column conditions of several crater lakes in Costa Rica is presented, and related to their morphometry and elevation. The significance for their limnology is also discussed. Data were gathered during several research projects that were supported by the University of Costa Rica. 


\section{METHODS}

Lakes were visited several times as part of different studies performed at CIMAR, at least during one year period. Lake Barva was sampled between May 1994 and February 1999, Botos Lake was sampled between May 1994 and August 1996, Cerro Chato lake between May 1992 and November 1996, and Hule Lake between August 1990 and June 1991. During each visit a sampling station was located in the center of the lake. At this point the water temperature and dissolved oxygen were measured every meter to the bottom of the lake with electronic field equipment (YSI ${ }^{\circledR}$ ). Additionally, the Secchi disk transparency was determined in each occasion on each lake.

Depth soundings were performed on each lake, at least following one diameter transect across the lake, and in some occasions several transects were performed in some lakes. Lake area was determined from topographic maps or taken from surveys performed by the National Geographic Institute (IGN) of Costa Rica. Altitude for each lake was also taken from topographic maps.

\section{DESCRIPTION OF THE LAKES}

The basic morphometric characteristics of each lake are summarized in Table 1. Barva Lake is located at $2840 \mathrm{~m}$ above sea level. It is a small lake (surface area of $1.0 \mathrm{ha}$ ) and $7 \mathrm{~m}$ deep, but with a relative depth of 6.2. The crater around it rises up 20 to $40 \mathrm{~m}$ above the water level, and has a maximum diameter of $140 \mathrm{~m}$. Botos Lake is a cold water lake in a dormant crater in Poás volcano. It is at $2600 \mathrm{~m}$ above sea level, with a surface area of $10.3 \mathrm{ha}$, with $9 \mathrm{~m}$ of depth, and a relative depth of 2.5. The crater rises from 80 to $110 \mathrm{~m}$ above the water level, but it is wide and has a maximum diameter of $815 \mathrm{~m}$. Cerro Chato Lake is another crater lake at the summit of a volcanic structure that was the remnant of an explosion. The lake is located at $1020 \mathrm{~m}$ above sea level, it has 2.75 ha of surface area and $18 \mathrm{~m}$ of maximum depth, the relative depth is of 9.6. The crater around it rises from 60 to $120 \mathrm{~m}$ above the water level, with steep walls and a maximum diameter of $570 \mathrm{~m}$. Hule Lake is located within a caldera, at $740 \mathrm{~m}$ above sea level, with 54.7 ha of surface area, and $22.5 \mathrm{~m}$ of maximum depth; its relative depth is of 2.7. The caldera rim rises from 130 to $220 \mathrm{~m}$ above the lake surface but it is incomplete, and has a secondary volcanic cone to the northeast of the lake; the maximum diameter of the rim around the lake is $1725 \mathrm{~m}$ long.

\section{RESULTS}

\section{Barva Lake}

Surface temperature at Barva Lake varied between $11.5^{\circ} \mathrm{C}$ and $18^{\circ} \mathrm{C}$, whereas bottom temperature varied between 10.0 and $16.4{ }^{\circ} \mathrm{C}$ (Table $2)$. The vertical temperature change was also variable, between 0.0 and $6.5^{\circ} \mathrm{C}$. The greater temperature vertical gradients were observed in the

Table 1

Altitude and morphometric charateristics of the craters lakes

\begin{tabular}{|c|c|c|c|c|}
\hline Lake & Barva & Botos & Chato & Hule \\
\hline Altitude (m asl.) & 2840 & 2600 & 1020 & 740 \\
\hline Min Rim altitude & 2860 & 2708 & 1080 & 870 \\
\hline Max Rim altitude & 2880 & 2680 & 1140 & 960 \\
\hline Crater max. diameter $(\mathrm{m})$ & 140 & 815 & 570 & 1725 \\
\hline Area $\left(\mathrm{hm}^{2}\right)$ & 1 & 10.3 & 2.75 & 54.7 \\
\hline Depth (m) & 7 & 9 & 17.9 & 22.5 \\
\hline Relative depth \% & 6.20 & 2.49 & 9.57 & 2.70 \\
\hline
\end{tabular}


Table 2

Summary of temperature, dissolved oxygen, thermocline depth, mixing depth, and Secchi depth of the crater lakes

\begin{tabular}{ccccc}
\hline Lake & Barva & Botos & Chato & Hule \\
\hline Thermocline depth $(\mathrm{m})$ & $3-4$ & -- & $3-7$ & $4-7$ \\
Relative Mixing depth & 0.57 & 1.00 & 0.45 & 0.31 \\
Surface max T $\left({ }^{\circ} \mathrm{C}\right)$ & 1 & 19 & 25 & 26.5 \\
Surface min T $\left({ }^{\circ} \mathrm{C}\right)$ & 11.5 & 12.8 & 18.8 & 22.2 \\
Diff. Surf. Temperature & 6.5 & 6.2 & 6.2 & 4.3 \\
Bottom max T $\left({ }^{\circ} \mathrm{C}\right)$ & 16.4 & 19 & 22 & 21.3 \\
Bottom min T $\left({ }^{\circ} \mathrm{C}\right)$ & 10 & 12.8 & 3.2 & 20.8 \\
Diff. Bottom Temperature & 6.4 & 6.2 & 1.65 & 0.5 \\
Secchi max $(\mathrm{m})$ & 2.3 & 8 & 1 & 3.47 \\
Secchi min $(\mathrm{m})$ & 0.9 & 4.9 & 0.21 & 2.85 \\
Secchi/Mix. Depth & 0.58 & 0.89 & & 0.50 \\
\hline
\end{tabular}

moths from May to August (Figure 1A), although a homoeothermic water column can be observed at any time in the year (Figure 1C).

The dissolved oxygen in Barva Lake was usually high at the surface, between 10.0 and 5.2 $\mathrm{mg} \cdot \mathrm{l}^{-1}$, but could reach almost anoxia conditions at the bottom $\left(7.6\right.$ to $\left.0.9 \mathrm{mg} \cdot \mathrm{l}^{-1}\right)$. When there was a sharp decrease of oxygen levels, it usually occurred at 3 to $4 \mathrm{~m}$ of depth (Figure 1C). A strong vertical gradient in dissolved oxygen could be observed at any time during the year (Figure 1D).

The visibility of the Secchi depth ranged from 0.9 to $2.3 \mathrm{~m}$, with an average of $1.4 \mathrm{~m}$, but there was not a seasonal pattern in Secchi variation.

\section{Botos Lake}

The water temperature ranged between $19^{\circ} \mathrm{C}$ and $12.8^{\circ} \mathrm{C}$ in the whole water column (Table 2). Although a gradient of $1^{\circ} \mathrm{C}$ was observed in a few occasions, especially in the months from March to August, the change occurred just beneath the surface, and the water column was homoeothermic below $1 \mathrm{~m}$ depth in all occasions (Figures 2A and $2 \mathrm{C}$ ). The dissolved oxygen was high in most occasions, with a maximum of $9.2 \mathrm{mg}^{-l^{-1}}$ at the surface and a minimum of $5.0 \mathrm{mg} \cdot \mathrm{l}^{-1}$ at the bottom (Figure $3 \mathrm{~B}$ ). This minimum oxygen value occurred in August 1995, when the lake was otherwise, homoeothermic (Figure 3D).

The water was quite transparent, with Secchi disk readings between 4.9 and $8 \mathrm{~m}$, when actually the Secchi disk sat on the bottom with the line loose and was still clearly visible.

\section{Cerro Chato Lake}

In this lake the water temperature changed between 25 and $18^{\circ} \mathrm{C}$ at the surface, and between 22 and $18^{\circ} \mathrm{C}$ at the bottom (Table 2). The lake showed a thermocline at about 4 to $8 \mathrm{~m}$ (Figure $3 \mathrm{~A}$ ), especially in the months from May to August (Figure 5C). Dissolved Oxygen levels can reach to between 7.2 and $10.6 \mathrm{mg}^{-1} \mathrm{l}^{-1}$ at the surface, and decrease from 4.8 to anoxia at the bottom. Oxyclines developed below $8 \mathrm{~m}$ of depth (Figure 3B). Anoxic conditions occur generally during the months of May to August, when most of the largest differences were observed (Figure 3D). The Secchi transparency was always less than $2 \mathrm{~m}$ (between 1.65 and $1.0 \mathrm{~m}$ ), and was lowest during the rainy season.

\section{Hule Lake}

In Lake Hule the surface temperature ranged between 26.5 and $22.2{ }^{\circ} \mathrm{C}$, and at the bottom between 
Temperature $\left({ }^{\circ} \mathrm{C}\right)$
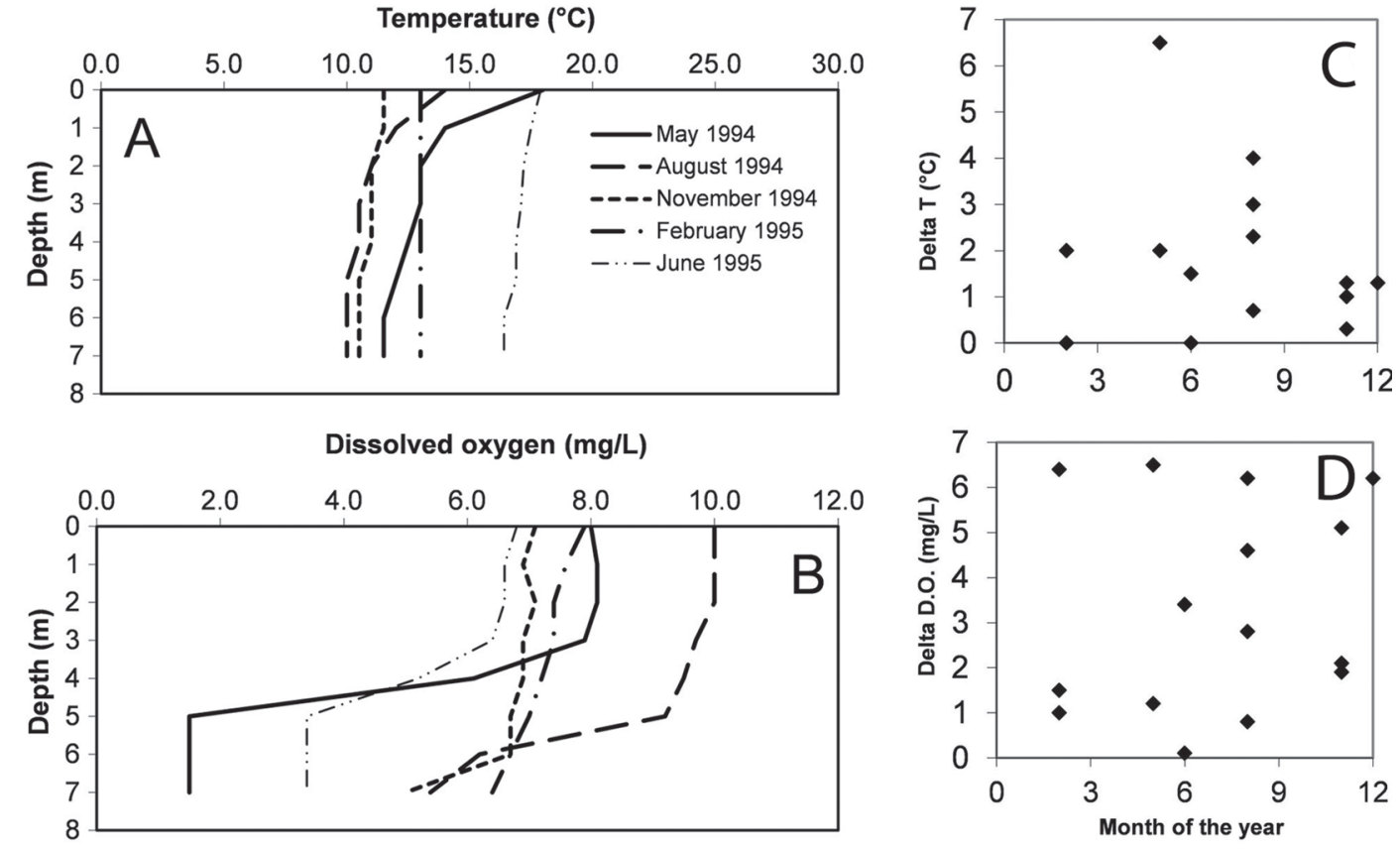

Fig. 1: Examples of vertical profiles of temperature (A) and dissolved oxygen (B) in Barva Lake, taken between 1994 and 1995. Variation of the change in temperature (C) and dissolved oxygen (D) between surface and bottom in Barva Lake according to the month of the year of sampling. Data taken between 1994 and 1999.
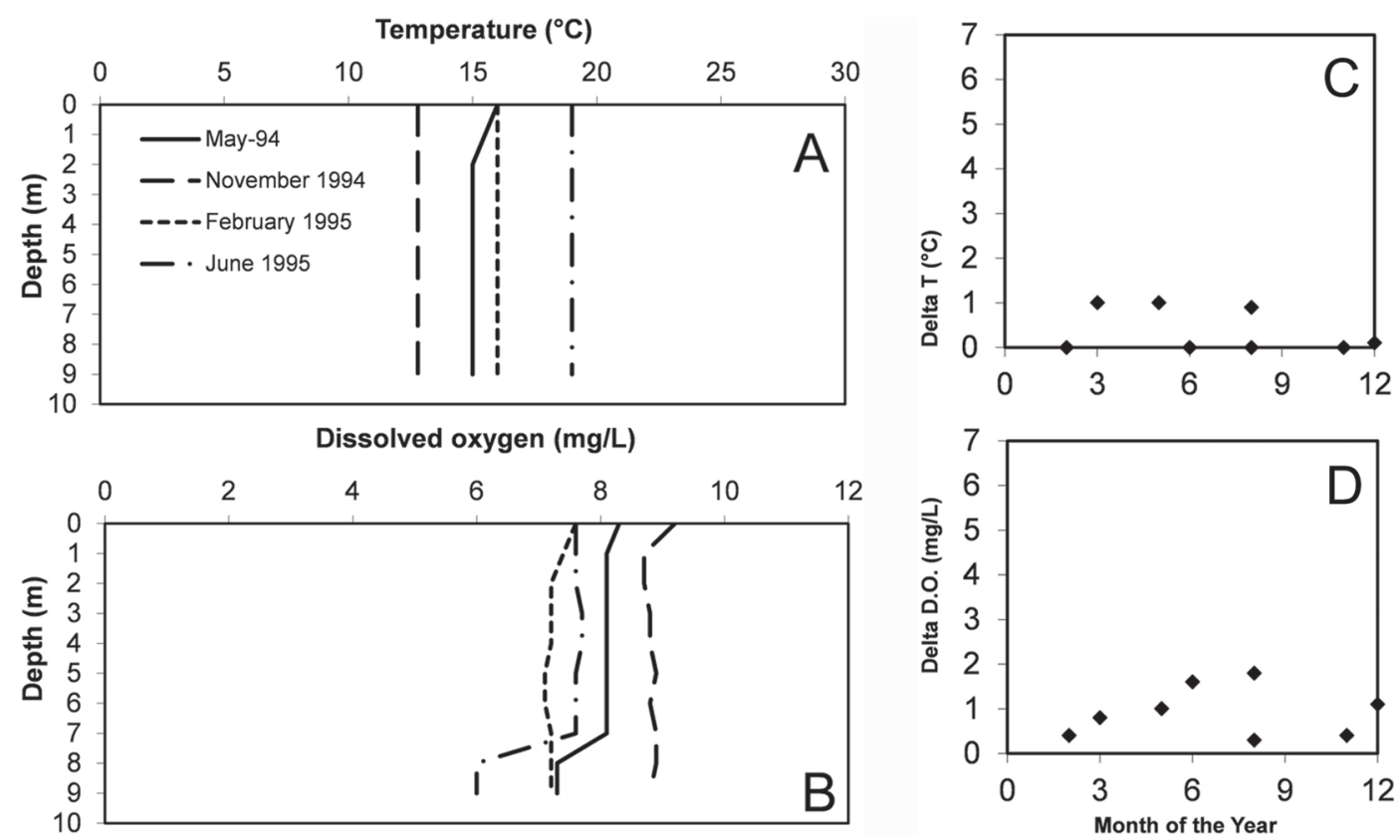

Fig. 2: Examples of vertical profiles of temperature (A) and dissolved oxygen (B) in Botos Lake, taken in 1994 and 1995. Variation of the change in temperature (C) and dissolved oxygen (D) between surface and bottom in Botos Lake, according to the month of the year of sampling. Data taken between 1994 and 1996. 

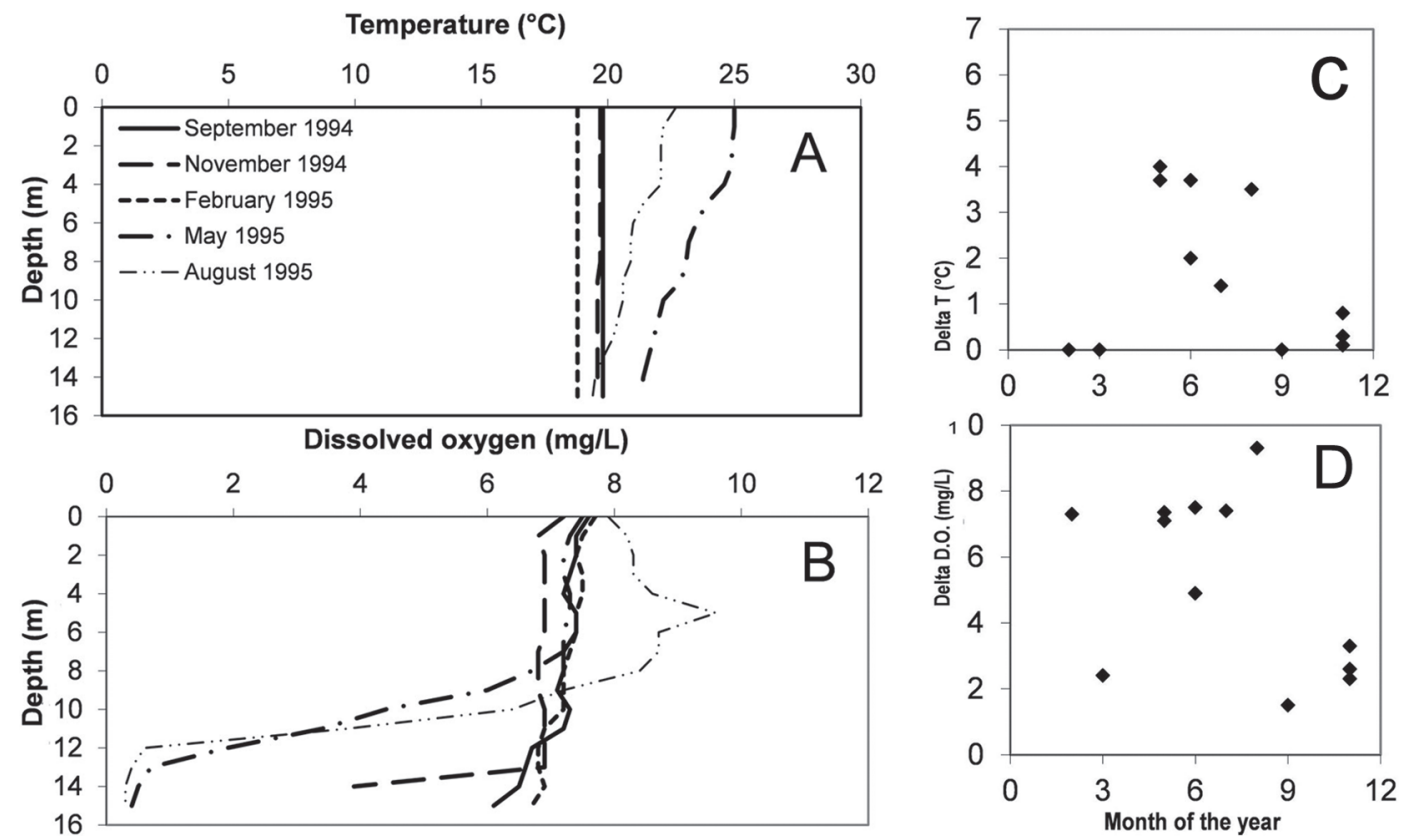

Fig. 3: Examples of vertical profiles of temperature (A) and dissolved oxygen (B) in Cerro Chato Lake, taken in 1994-1995. Variation of the change in temperature (C) and dissolved oxygen (D) between surface and bottom in Cerro Chato Lake, according to the month of the year of sampling. Data taken between 1992 and 1996.

21.3 and $20.8{ }^{\circ} \mathrm{C}$ (Table 2). The lake was visited in four occasions along a year to cover the main seasonal conditions, in all instances the lake was stratified with a thermocline that varied between 4 and $7 \mathrm{~m}$, being deeper in the months of February and November, which coincide with the trade wind season (Figure 7A). The level of dissolved oxygen varied between 9.4 and $6.8 \mathrm{mg}^{-1} \mathrm{l}^{-1}$ at the surface, and was anoxic at the bottom, below $4 \mathrm{~m}$ of depth in most occasions, except in February when it was anoxic below $7 \mathrm{~m}$ of depth (Figure 7B). Secchi depth varied between 2.85 and $3.47 \mathrm{~m}$.

\section{DISCUSSION}

These four lakes differ in their shape and altitude, which is the result of the activity of each particular volcano, but also differ in their limnological characteristics. The lakes located at higher elevation, as Barva and Botos, were expected to show a clear polymictic behavior since they have low temperatures, and any heat that buildup during the day should be lost during the night, enhancing vertical mixing. However, Barva Lake showed signs of vertical stratification that may last at least for a few days, as indicated by the oxygen profiles, which is also associated with seasonal weather, as opposed to what occur in Botos Lake, where the water column warms up and cools down along the year, but is always well mixed to the bottom. Other crater lakes, as Cerro Chato's and Hule, which are located at lower elevations, have higher temperatures and are more prone to have a stratified water column.

One factor that affects this behavior is the shape of the lake. Botos and Barva lakes could be classified as shallow lakes according to criteria established by Lewis (1983), since they are less than 10 $\mathrm{m}$ deep. However, Barva has a shape which yields a high relative depth value and this fact hinders frequent mixing by winds. Since it is located within a crater and has a low fetch, the winds that are able to blow over its surface are much reduced and can only mix the lake when they are very strong, and 


\section{Temperature $\left({ }^{\circ} \mathrm{C}\right)$}

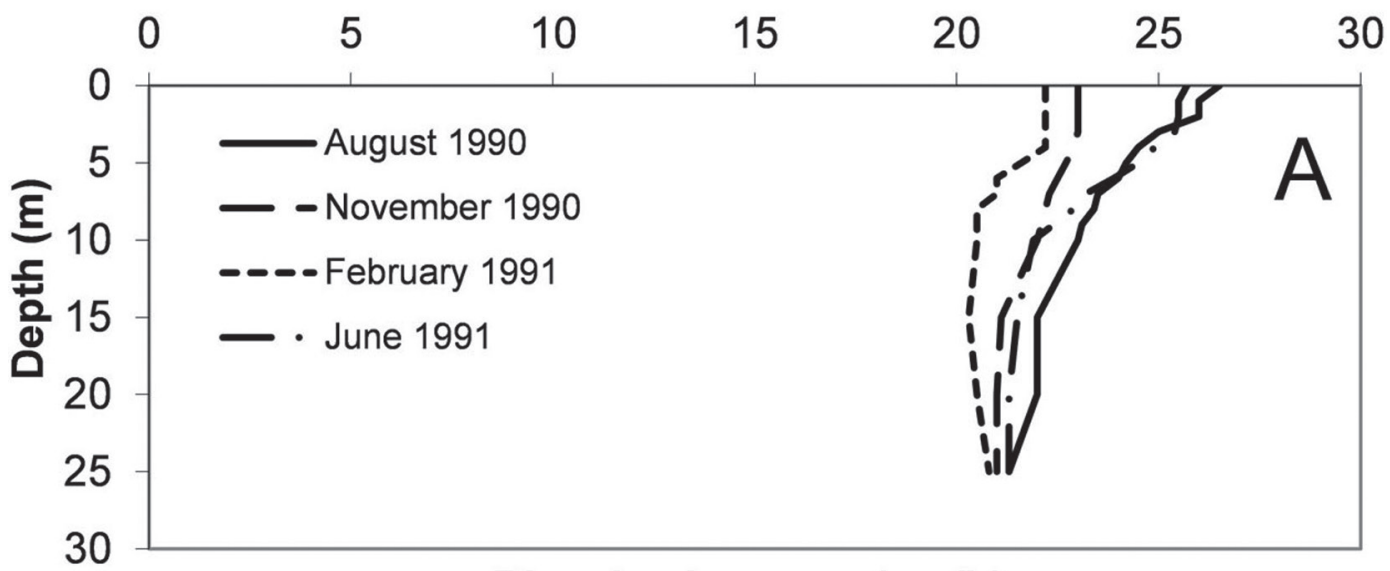

Dissolved oxygen (mg/L)

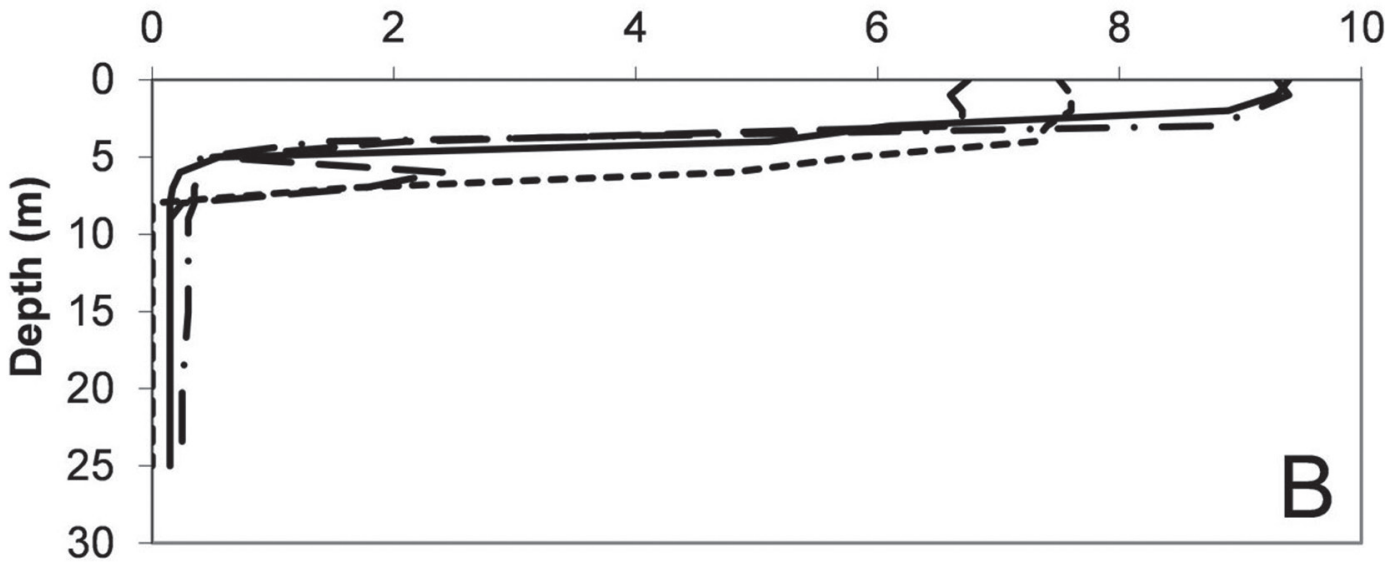

Fig. 7: Examples of vertical profiles of temperature (A) and dissolved oxygen (B) in Hule Lake, taken in 1990 and 1991.

occur coupled with cold weather. It has a similar behavior as Lake San Pablo, in Ecuador, which is located at a similar elevation but is deeper and with a lower relative depth (Gunkel \& Casallas, 2002). In lake Botos, on the other hand, the lake has a wide, exposed surface, and the wider crater allows the wind to mix thoroughly the lake which did not develop a stratification although in some occasions a surface warming was evident by midday, during the samplings. Both lakes show a rapid response to weather variations, as explained by Chapman et al. (1998), but Botos mixes completely continually, whereas Barva stratifies for at least brief periods, depending on weather conditions.
Cerro Chato's Lake has also a high relative depth, which means that it is too deep for its surface area. Besides it is located within a crater covered by forest, and although the wind can mix it down to the bottom during the colder months of November through February, it stratifies and develops an anoxic hypolimnion. At a lower elevation, Hule Lake is always stratified although it has a lower relative depth, comparable to Botos Lake, but here the higher temperatures and the local weather prevent to lake to mix completely, at least during the period of study. A similar conclusion was reached by Gocke (1997), where he describe a deeper mixing event in January and 
February 1989 which compromised only the upper layers of the hipolimnion.

As can be seen from this brief comparison, the behavior of these crater lakes is the combined result of size, shape and location. The fact that the lakes lie within craters, whose walls emerge tall and steep from the lakes shores, does not prevent mixing, as may occur in Barva and Chato. But the shape of the lake, mainly its relative depth compared to its surface area, influences the frequency of the mixing and allow for stratified periods when enough heating accumulates at the surface. Similar conclusions have been established from the study of crater lakes in Uganda, Ethiopia, Cameroon, New Zealand and Mexico (Baxter et al., 1965; Chapman et al., 1981; Kling, 1988; Chapman et al., 1998; Vásquez et al., 2004). On the other hand, Botos and Hule lakes have a different limnology not necessarily based on their shapes, but on their different altitude, Botos, at a higher elevation is continuous polymictic whereas Hule, at lower and warmer conditions is oligomictic. Ramírez \& Camacho (1991) sampled the lake from April to September 1989 and found that it was also stratified with an anoxic hypolimnion in all occasions. Deeper mixing in Lake Botos could also be enhanced by its clearer waters, as suggested for crater lakes in Cameroon (Kling, 1988) and lakes in Canada (Mazumder \& Taylor, 1994).

There have been two proposals of lake classification, Hutchinson and Löffler's (1956) original work based the classification on latitude and altitude, and Lewis' (1983) model, which used lake depth instead of altitude. The comparison of these four lakes shows that both, altitude and lake depth are important in determining the limnological characteristics of these crater lakes, but it seems that it is not only the absolute depth, but the relative depth, that is, the shape of the basin, which influences the mixing pattern of the lake. Additional work should be needed to incorporate data on more lakes, of different shapes and locations to elucidate better this relationship.

\section{AKNOWLEDGEMENTS.}

This research has been possible through two main fundings (808-89-063 and 808-94278) granted by the Vicerrectory of Research of the University of Costa Rica to the Center for Research on Marine Sciences and Limnology (CIMAR). I am grateful to Carlos Jiménez, Monika Springer, Carlos Ugalde, Sussy Segura, Esteban Estrada, Astrid Michells, and Gregorio Dauphin, who made the field work possible in these cool tropical lakes.

\section{REFERENCES}

ALVARADO, G.E., SIGARÁN, C. \& PÉREZ W., 2000: Vulcanismo: sus productos y geoformas.- En: DENYER, P. \& KUSSMAUL S.(eds): Geología de Costa Rica.- Ed. Tecnológica de Costa Rica, Cartago: 133154.

BAXTER, R.M., PROSSER, M.V., TALLING, J.F. \& WOOD, R.B., 1965: Stratification in tropical African lakes at moderate altitude (1,500-2,000 m).- Limnol. Oceanogr. 10(4): 510-520.

CHAPMAN, M.A., JOLLY, V.H. \& FLINT, E.A., 1981: Limnology of lake Rerewhakaaitu.New Zeland J. Mar. Freshwat. Res. 15: 207-224.

CHAPMAN, L.J., CHAPMAN, C.A., CRISMAN, T.L. \& NORDLIE, F.G., 1998: Dissolved oxygen and thermal regimesof a Ugandan crater lake.- Hydrobiologia, 385: 201-211.

GOCKE, K. 1997: Basic morphometric and limnological properties of Laguna Hule, a caldera lake in Costa Rica.- Rev. Biol. Trop. 45(1B): 537-548. 
GUNKEL, G., \& CASALLAS, J., 2002: Limnology of an equatorial high mountain lake - Lago San Pablo, Ecuador: the significance of deep diurnal mixing for lake productivity.- Limnologica, 32: 33-43.

HABERYAN, K.A. \& HORN, S.P., 1999: Chemical and physical characteristics of seven volcanic lakes in Costa Rica.Brenesia, 51:85-95.

HABERYAN, K, HORN, S.P. \& UMAÑA, G., 2003: Limnology of fifty-one lakes in Costa Rica.- Rev. Biol. Trop. 51(1):107122.

HABERYAN, K.A., UMAÑA, G., COLLADO, C. \& HORN, S.P., 1995 Observations on the plankton of some Costa Rican lakes.Hydrobiologia, 312: 75-85.

HORN, S.P. \& HABERYAN, K.A., 1993: Physical and chemical properties of Costa Rican lakes.- Nat. Geogr. Res. and Exploration, 9(1): 86-103.

HUTCHINSON, G.E. \& LÖFFLER, H. 1956: The thermal classification of lakes.- Proc. Nat. Acad. Sci., 42: 84-86.

KLING, G.W. 1988: Comparative transparency, depth of mixing, and stability of stratification in lakes of Cameroon, West Africa.Limnol. Oceanogr. 33(1): 27-40.

LEWIS, W.M., JR., 1983: A revised classification of lakes based on mixing.- Can. J. Fish. Aquat. Sci. 40: 1779-1787.
MAZUMDER, A. \& TAYLOR, W.D., 1994: Thermal structure of lakes varying in size and water clarity.- Limnol. Oceanogr. 39(4): 968-976.

MELACK, J.M. 1978: Morphometric, physical and chemical features of the volcanic crater lakes of Western Uganda.- Arch. Hydrobiol. 84: 430-453.

RAMÍREZ, E. \& CAMACHO, L., 1991: Estudio preliminar de la Laguna Hule, Costa Rica.Uniciencia, 8(1-2): 17-25.

UMAÑA V., G., 1990: Limnología básica de la laguna del Barba, Costa Rica.- Rev. Biol. Trop. 38(2B): 431-435.

UMAÑA V., G., 1993: The planktonic community of Laguna Hule, Costa Rica.- Rev. Biol. Trop. 41(3): 163-171.

UMAÑA V., G., 1997: Basic limnology of Lago Bonilla, a Tropical lowland lake.- Rev. Biol. Trop. 45(4): 1429-1437.

UMAÑA V., G. 2001: Limnology of Botos Lake.Rev. Biol. Trop. 49 (supl.2): 1-10.

UMAÑA V., G. \& JIMÉNEZ, C., 1995: The basic limnology of a low altitude tropical crater lake: Laguna del Cerro Chato, Costa Rica.Rev. Biol. Trop. 43(1-3): 131-138.

VÁSQUEZ, G., FAVILA M.E., MADRIGAL, R., MONTES DEL OLMO, C., BALTANÁS, A. \& BRAVO, M.A., 2004: Limnology of crater lakes in Los Tuxtlas, Mexico.Hydrobiologia, 523: 59-70. 